\title{
KÖZÚTI KÖZLEKEDÉSI ESZKÖZÖK ÚJRAHASZNOSÍTÁSÁNAK KAPACITÁS-IGÉNY FELMÉRÉSE ÉS JÁRMÜBONTÓ TERVEZÉSE/FEJLESZTÉSE LOGISZTIKAI ESZKÖZÖKKEL
}

\author{
Erdei László \\ PhD hallgató, Miskolci Egyetem, Logisztikai Intézet \\ 3515 Miskolc, Miskolc-Egyetemváros, e-mail: erdei.laszlo1995@gmail.com
}

\begin{abstract}
Absztrakt
A körforgásos gazdaság célkitüzéseinek megvalósitása nagymértékben függ a hulladékkezelési feladatok logisztikai problémáinak megoldásától. A közösségi közlekedés területén bekövetkezö automatizálás és digitalizáció hozzájárul az adott jármüállomány gyors lecserélödéséhez, ezért szükséges megoldani a leselejtezett eszközök hatékony kezelését. Jelen cikk keretében bemutatásra kerül a körforgásos gazdasági modellnek megfelelö jármübontó kapacitásigény-felmérése a közúti közösségi közlekedési eszközök tekintetében. Majd egy jármübontó külsö és belsö logisztikai folyamatait érintő tervezési és fejlesztési eszközök kerülnek ismertetésre.
\end{abstract}

Kulcsszavak: körforgásos gazdaság, inverz logisztika, hulladékkezelés

\begin{abstract}
The implementation of the circular economy depends on solving the logistical problems of waste management tasks. Achieving the objectives of the circular economy depends to a large extent on solving the logistical problems of waste management tasks. In the field of public transport, automation and digitalisation contribute to the rapid replacement of the vehicle fleet, therefore it is necessary to deal with the cull/obsoletelend-of-life equipment. In this article, the assessment of scrap yard capacity requirement of circular economy model in regard to road public transport vehicles is presented. Furthermore, design and development tools for the external and internal logistics processes of a vehicle dismantler/scrap yard is described.
\end{abstract}

Keywords: circular economy, inverse logistics, waste management

\section{Gazdasági háttér}

A termelő vállalatok tevékenységei minden esetben illeszkednek egy adott gazdasági struktúrába. Ezek a gazdasági struktúrák többfélék is lehetnek, de számosságuk kötött. Az 1. ábra bemutat három gazdálkodási modellt. Ezek között két véglet létezik. A lineáris gazdaság során nincs visszacsatolás a modell bármely két pontja között. Ebben az esetben a kitermelt anyagok mennyisége egyenesen arányos a termékéletút végén keletkező hulladékok mennyiségével. A nyílt láncú gazdaság elve a

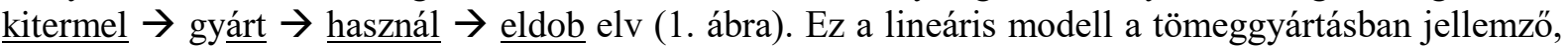
ahol alacsonyak a termelési költségek. Ezt alkalmazva elvész a termékbe fektetett munka és energia, nem említve a hulladékmennyiségek növekedését és a természeti erőforrások kimerítéséhez történő hozzájárulást. A lineáris gazdasági modell hosszú távon fenntarthatatlan, így különböző megoldásokkal környezettudatosabbá lehet tenni ezeket a folyamatokat. Az egyes kimenetek során keletkező hulladékokat, vagy az elhasznált termékeket visszaáramoltatással újra fel lehet használni a 
gyártási tevékenységek során. Ezzel megspórolható alapanyag és energia. Az újrahasznosítási ciklusok láthatóan pozitívak. Az ismert pozitív hatások maximalizálásaként jött létre a körforgásos gazdasági modell, amely a lineáris gazdasággal szemben a másik végletet jelenti. Ideális esetben a körforgásos gazdasági modell törekvéseinek az alkalmazásával elérhető a zéró hulladéktermelés. Elméletben igazolható, viszont a gyakorlati kivitelezéshez számos erőfeszítésre és jogi szabályozásra van szükség. [1]

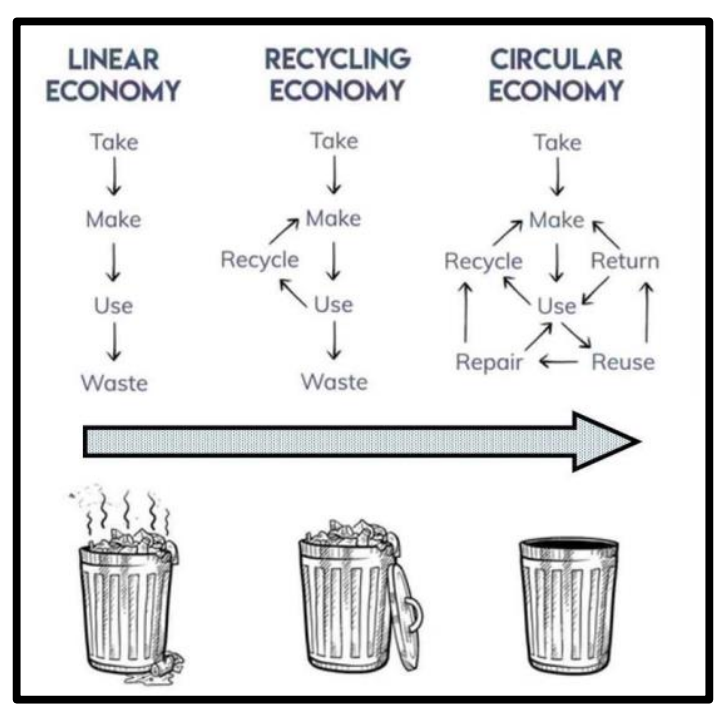

1. ábra. Különbözö gazdasági modellek [2]

Ahogyan felgyorsult a világunk, úgy a termékek életciklusa is lerövidült. Manapság már nem a használati eszközeink tönkremenetele generálja az újabb termékek vásárlását. Erre a társadalmi folyamatra reagálva a gyártók igyekeznek a termékeikből mind nagyobb mennyiségeket elöállítani, viszont ezen termékek tervezhető hasznos élettartama lényegesen lerövidült. A körforgásos gazdaság elmélete ösztönzi a gyártót, hogy megújuló forrásokat használjon egy-egy termék előállításához, illetve, hogy a tervezési folyamatok során vegye figyelembe a termékének a jövőbeli hatékony újrafelhasználási tulajdonságait is. [3]

A körforgásos gazdaságot két irányból lehet megközelíteni. Az egyik a biológiai anyagokra vonatkozik, a másik pedig a technológiai oldal, ami a múszaki anyagokra vonatkozik. Mint müszaki emberek, mi erröl az oldalról vizsgáljuk a modellt. Egy termék esetében megfigyelhető az életút, amely már fentebb is említésre került. A termék első meghibásodásakor nem kell azonnal megszabadulni tőle, vagy leselejtezni. Az első visszacsatolás során (ad hoc, vagy megelőző) karbantartási munkálatokkal visszaállítható az eszköz/berendezés a rendeltetés szerinti működési állapotába. Amint már az előző eljárást nem lehet sikeresen alkalmazni, akkor a használt áron történő értékesítéssel is meg lehet óvni az eszközt attól, hogy hulladékként végezze. Egy elavult, vagy leselejtezett eszköz/berendezés alkatrészeit, vagy egyes részegységeit újra lehet használni egy újszerü, vagy egy felújításra váró eszköz/berendezés karbantartása során. Ha ez sem járható út már, akkor az anyagában történő újrahasznosítással újra visszakerülhet a körforgásba az elavult, vagy leselejtezett eszköz/berendezés része/anyaga. Amennyiben már erre sem lesz alkalmas az anyag, akkor energetikai célú újrahasznosítással elégethető, vagy ha energianyerésre sem hasznosítható, akkor ártalmatlanítják és hulladéklerakóban helyezik el az anyagot. 
A modell lényege tulajdonképpen az, hogy minél többször lehessen visszacsatolni a gazdasági körforgásba az elhasználódott eszközöket, vagy azok részegységeit, anyagait. Ezzel is törekedni kell arra, hogy minimalizálható legyen az energetikai célú újrahasznosítás, vagy a lerakókban való elhelyezés. [4]

A körforgásos gazdasági modell az elmúlt 5 évben nagy hangsúlyt kapott egyes jogszabályokban és nemzetközi programokban. Az ENSZ 2015-ben elfogadta a Fenntartható Fejlödés Céljait szolgáló programot, így az EU Bizottsága célul tüzte ki ezen program céljait (2015-ben elfogadott „Körkörös Gazdasági Akcióterv"). Ez alapján 2030-ig az EU tagállamoknak 50\% alá kell csökkenteni a keletkezett hulladékok lerakókba való elhelyezésének arányát. Ezzel már hatást tudnak gyakorolni mikrogazdasági szinten is arra, hogy a gyártóvállalatok minél több szinten legyenek hajlandók visszaforgatni az elhasználódott eszközöket, vagy annak egységeit. [5] Viszont még mielőtt a körforgásos gazdasági modell ennyire felkapottá vált volna a sajtóban és a tudományos életben is, megelőzte már számos megegyezés és direktíva, amely nagymértékben támaszkodik a logisztikai rendszerszemlélethez. Számos EU szintü megegyezés és direktíva az elhasznált és leselejtezett jármüvek területén vezetett ahhoz, hogy számos országos és nemzetközi társulás alakult ki meghatározott területeken való együttmüködés céljából. Ezek általában megegyeznek abban, hogy az újrahasznosítást a piacgazdaság törvényei szerint kell végrehajtani.

Az újrahasznosítási társulások bizonyos szolgáltatók és kezelők úgynevezett szövetkezetei. Itt a különböző résztvevők feladatai elemi szinten definiálhatók. Elsősorban a gyártók feladatai, hogy a jármüvek tervezése és az anyagok kiválasztása során figyelembe vegyék a környezetvédelem követelményeit és részt vállaljanak az újrahasznosítási technológia kidolgozásában. Továbbá megfelelő adatokat kell szolgáltatniuk az újhasznosítás és ártalmatlanítás környezetkímélő végrehajtásához és megoldásokat kell kidolgozniuk az újrahasznosított anyagoknak a jármüiparban és egyéb területeken való felhasználására. [4] Az újrahasznosító és hulladék-feldolgozó ipar feladatai közé sorolhatók_az elhasználódott jármüvek összegyüjtése, a begyüjtött roncsok anyagának feltárása, majd a begyüjtési, újrahasznosítási és ártalmatlanítási folyamatok végrehajtása és dokumentálása, illetve az újrahasznosítással kapcsolatos információknak a hatóságokhoz való továbbítása. A kormányzat részéről a feladat a támogatási és megfelelő törvényes keretek kialakítása a környezetvédelem és a gazdasági tevékenység számára. Továbbá egy alkalmas szervezet kialakítása, amely biztosítja a jármüvek megjelölt gyüjtőhelyeken való átvételét (igazolások kiadása stb.). Ezen sorok is jól példázzák, hogy együttesen minden társadalmi szereplőnek kölcsönösen felelősséget kell vállalnia és lépéseket kell tenni a fenntartható fejlődés irányába. [6]

Az előző témához kapcsolódóan szükséges említést tenni az olyan termékekröl, amelyek előállítása és forgalmazása során az okozott környezeti veszélyeztetettség fennállása magas, így környezetvédelmi termékdíjat szabnak ki rájuk az illetékes hatóságok (későbbiekben csak termékdíj). Hazánkban a 2011. évi LXXXV. törvény rendelkezik a termékdíjak teljeskörü szabályozásáról. A termékdíjból befolyt összegek a fent említett anyagok környezetkímélő kezelésére fordíthatók a hulladékká válás után. A környezetvédelmi termékdíj megfizetése minden esetben a fogyasztót terheli. [7] Mivel a szabályozás csak egyes anyagokra/termékkörökre terjed ki és a komplex szerkezeteknek minősülő jármüvek jelenleg nem tartoznak a szabályozás hatálya alá, így a fent említett lehetséges jármübontást is profitorientált tevékenységként kell majd kezelni (nincs lehetőség a finanszírozásban a termékdíjakból befolyt összeg közvetlen felhasználására). [8] Ezzel pedig az elhasznált jármúvek újrahasznosítására vonatkozó üzleti modellt eszerint kell felépíteni és a lehetséges mủveletek és folyamatok összességének a hatékonyabbá tétele lesz a cél. 


\section{Jármúbontási kapacitás-igény vizsgálata}

Egy bontóüzem fő profilja a járművek bontása, szétszerelése és a keletkezett komponensek újrahasznosításra való előkészítése (osztályozás, tárolás, előfeldolgozás pl. aprítás, préselés). Ezen fajta járművek lehetnek buszok, teherautók, trolibuszok és kötöttpályás járművek, mint például villamosok. Egy bontóüzemnek multifunkcionálisnak kell lennie, ezért a különböző bemenő raktárakat és munkaállomásokat úgy kell kialakítani, hogy képesek legyenek a különféle paraméterü járműveket széles körben kezelni. Különösen nagyszámú Magyarországon az idős autóbusz állomány. Így az autóbuszok esetére vonatkoztatva végzünk kapacitásigény-számítást a következőkben.

1. táblázat. Hazai forgalomban lévö autóbuszok eloszlása statisztikai korcsoportok alapján [9]

\begin{tabular}{|c|c|c|c|}
\hline Összes jármü & $\mathbf{0}-\mathbf{5}$ éves & $\mathbf{6}-\mathbf{1 5}$ éves & $\mathbf{1 6}$ évesnél régebbi \\
\hline 18.475 & 2.586 & 9.005 & 6.884 \\
\hline
\end{tabular}

Az 1. táblázatban a Központi Statisztikai Hivatal adatbázisából a 2016. évre vonatkozó statisztikai adatokat mutatjuk be. A BKV-nál a 2000-2016 között leselejtezett autóbuszok súlyozott átlagéletkora 18,76 év. Ezen adatot összevetve az 1. táblázatban közöltekkel megállapíthatjuk, hogy Magyarországra jellemző a túlkoros tömegközlekedési jármüállomány, ezen kívül pedig a fiatalabb buszok egyre csökkenő teljesítőképessége szempontjából meghatározható, hogy a leselejtezési életkort 16 évnél érdemes meghúznunk. Az egyre csökkenő teljesítőképesség betudható a mindennapi és ipari berendezések esetén megfigyelhető nagyobb számú és korábban bekövetkező meghibásodásoknak. Továbbá fontos megemlíteni, hogy a 16 évnél idősebb autóbuszok például a BKV flottájában nagyszámban a régi Ikarus típusú autóbuszok. Ezek az idősebb autóbuszok a magas futásteljesítmény mellett egyúttal nagyobb karbonlábnyommal is rendelkeznek, mint a fiatalabb és magasabb EURO motorbesorolású autóbuszok. Ezáltal kijelenthetjük, hogy egy jármü leselejtezéséhez nem csak negatív müszaki állapot vezethet, hanem környezeti és helyi szabályozások és a modernebb jármüvek vásárlása/lízingelése. S így a leselejtezési kor általánosságban megállapítható 16 évnél az autóbuszok esetében.

Az 1. táblázatban láthatjuk, hogy a 16 évesnél idősebb autóbuszok aránya meghaladja a 37\%-ot (6.884 db), a 6-15 évig terjedő korcsoport (ez egy 10 évet felölelö időtartam) pedig a 48\%-ot, a két csoport együttesen pedig a 86\%-ot a teljes autóbusz állományt figyelembe véve. Ebből következően az 5 évnél fiatalabb jármúvek aránya $14 \%$ alatt marad. Ezen adatok analizálásával következtetéseket tudunk levonni az autóbusz-bontóüzemek terhelésére az elkövetkezendő 15 évben.

A táblázatban lévő adatokat alapul véve indul az analízis. A 16 évnél idősebb korosztály a vizsgálat szerint a rendelkezésre álló jármümennyiség. A többi korosztály mennyiségével pedig úgy érdemes számolnunk, hogy az évek múlásával egyenletesen, átlag mennyiségü autóbuszok érik el a leselejtezési korhatárt. Így az évröl-évre várható bontandó jármüszám becslésére elöször érdemes megvizsgálni a 615 évig terjedő korcsoportot. Az éves bontású korfa szerinti darabszám-adatok hiányában átlagértékekkel lehet csak számolni. Ez alapján a 6-15 éves korcsoportba tartozó $9.005 \mathrm{db}$ jármüállományból évente kb. 900 db jármü kerül át a 16 évnél idősebb kategóriába, ezáltal nagy valószínűséggel leselejtezésre is. Tehát várhatóan egy $900 \mathrm{db} /$ év kapacitású bontóüzem feltehetően csak lépést tud tartani a leselejtezés ütemével, ha a már meglévő állomány nem csökken a következő 10 éves időszakban. A fajlagos munkanapok számát figyelembe véve, ami körülbelül 255 nap egy évben, a napi bontási kapacitás-igény értéke 3,53 db/nap az elkövetkezendő 10 éves időszakban. Az 
azt követő 5 éves időszakban a jelenleg 0-5 évig terjedő korcsoportot alkotó $2.586 \mathrm{db}$-os jármüflotta válik évröl évre selejtezésre éretté, ezt 5 évre egyenletesen felosztva átlagosan $500 \mathrm{db}$ körüli bontandó jármü várható évente, ami $\mathbf{2}$ db/nap érték körül mozog. Az utána lévő időszakban pedig a mostani beszerzésekkel arányosan várható leselejtezés. A 2016-ban meglévő 6884 db-os 16 évnél idősebb jármüállomány bontása ebben a 15 éves időszakban átlagosan napi $\mathbf{4 , 7 4} \mathbf{d b} / \mathbf{n a p o s}$ bontási kapacitásigényt jelent a meglévő adatok alapján.

A korcsoportok szerint megállapított bontási kapacitás-igényekből a levonható legföbb eredmény, hogy országos szinten is csak jelentős teljesítményü autóbuszbontó mühely kiépítésével nyílik lehetőség a probléma kezelésére. Viszont ekkora intenzitású bontásokra nem biztos, hogy célszerủ egy centralizált jármübontót létesíteni. Az előforduló jármümennyiségeket területi eloszlás alapján érdemes tovább vizsgálni és decentralizált módon keresni a megfelelő bontók földrajzi helyét centrumkeresési eljárás segítségével. Itt korlátozó feltételként lehetne kezelni a nagyobb buszflottát üzemeltető magyar társaságok már meglévő telephelyeit, ahol rendelkezésre állhat szakképzett munkaerő, megfelelő berendezések és igény a karbantartás, vagy felújítás során újraépíthető alkatrészekre.

A bemutatott, 15 éves időtartományra vonatkozó bontási kapacitás-igény prognózis a rendelkezésre álló adatokból, publikus felmérések alapján lett elvégezve. Ahogyan fent is említésre került, számos egyéb paraméter befolyásolja a leselejtezési hullámokat.

\section{Jármübontó tervezése, vizsgálata logisztikai eszközökkel}

\subsection{Külső logisztika}

$\mathrm{Az}$ egyik legfontosabb üzemen kívüli anyagmozgatási feladat az újrahasznosítandó jármúvek bontótelepre történő szállítása és ennek megtervezése. Ez a tervezési folyamat egy optimális földrajzi helyszín kijelölését jelenti, ami centrumkereséssel határozható meg.

A centrumnyomozás célfüggvénye (2. ábra): [10]

$$
\mathrm{C}=\sum_{i=1}^{n}\left(q_{i} \cdot l_{i}\right) \rightarrow \min .
$$

ahol:

$\boldsymbol{q}_{\boldsymbol{i}}$ - az $\boldsymbol{i}$-edik objektumból a centrumba elszállítandó anyagmennyiség a vizsgált időtartományban,

$\boldsymbol{l}_{\boldsymbol{i}}-\mathrm{a} \boldsymbol{i}$-edik objektum és a centrum közötti úthossz.

Az optimális helyszín meghatározható koordináták menti centrum nyomozással, habár ennél a módszernél a centrum helye nem a szállítás középpontja, hanem az anyagmozgatási súlypont $\varepsilon$-sugarú környezete. [10]

A rendszer $x-y$ koordináták szerinti súlypontja kiszámítható: [10]

$$
x_{s}=\frac{\sum_{i=1}^{n} q_{i} \cdot x_{i}}{\sum_{i=1}^{n} q_{i}} \quad \text { és } \quad y_{s}=\frac{\sum_{i=1}^{n} q_{i} \cdot y_{i}}{\sum_{i=1}^{n} q_{i}}
$$

ahol:

$\left\{\boldsymbol{x}_{\boldsymbol{s}} ; \boldsymbol{y}_{\boldsymbol{s}}\right\}-$ az $\boldsymbol{n}$ forráshelyböl álló rendszer anyagmozgatási munkájának súlyponti koordinátája,

$\boldsymbol{q}_{\boldsymbol{i}}-$ az $\boldsymbol{i}$-edik forráshelyről elszállítandó anyagmennyiség $[\boldsymbol{k g}]$,

$\left\{\boldsymbol{x}_{\boldsymbol{i}} ; \boldsymbol{y}_{\boldsymbol{i}}\right\}-$ az $\boldsymbol{i}$-edik forráshely $x$ - $y$ koordinátája. 


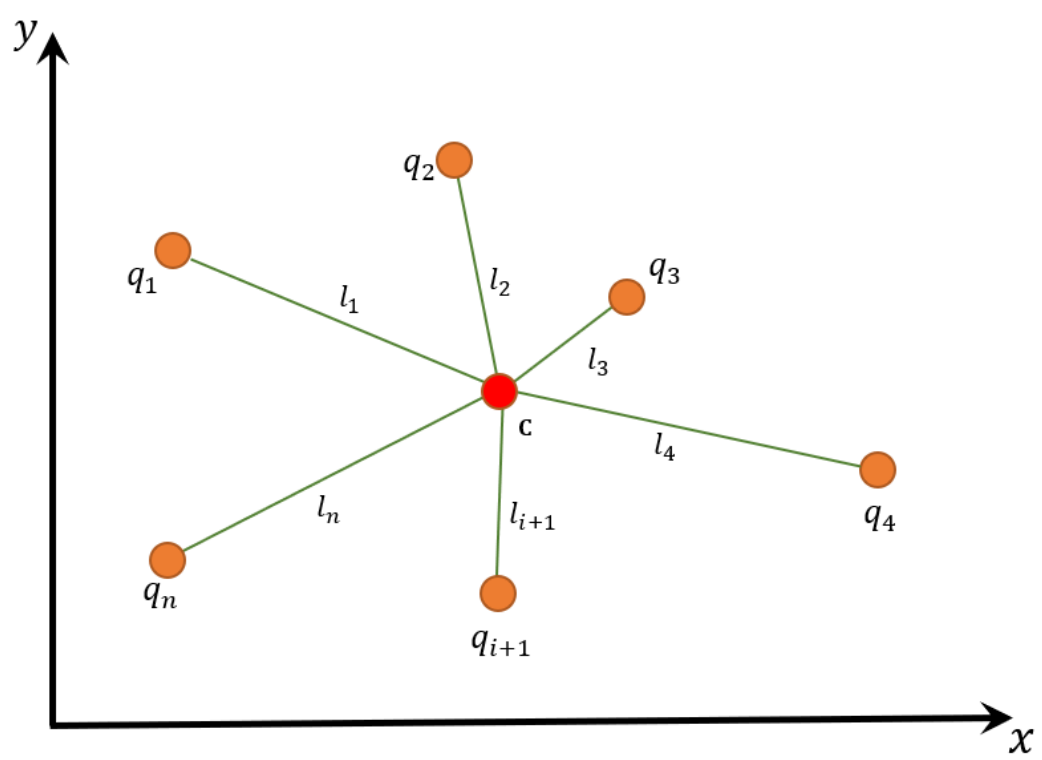

2. ábra. Centrumkeresési modell az optimális telephelyválasztáshoz [10]

A számítás eredményeként meghatározható egy optimális hely (centrum), ahová a forráshelyekről történő mennyiségek elszállítása a legkevesebb anyagmozgatási összmunkával jár. A külső logisztikai folyamatok tervezésekor a centrum helye elégséges megoldásnak tekinthetö. Célszerü egy jármübontót nem a centrumba, hanem a centrumtól legkisebb távolságú forráshelyre telepíteni. Ezáltal a legközelebbi forráshelyről szállítandó járművek szinte nulla anyagmozgatási munkával szállíthatók a bontómühelybe.

Az előző fejezetben meghatározott bontási kapacitás-igény prognózis tekintetében alkalmas az eljárás egy centralizált bontómühely földrajzi elhelyezéséhez [11], amelynél a bontandó jármüvek beszállításából adódó anyagmozgatási összmunka minimális.

\subsection{Belső logisztika}

Az üzemen belüli bontási tevékenységek feltételezik az anyag- és információáramlást az üzem egyes lokációi között. A 3. ábrán egy jármübontó objektumainak telephelyen belüli elrendezése látható az anyagáramlási irányokkal.

Egy jármübontó esetén szükséges egy szárazra fektető állomás kiépítése, ahol a veszélyes folyadékok eltávolítása történik. A veszélyes folyadékokat elsősorban a környezetre való kártékonyságuk miatt szükséges eltávolítani, illetve a további munkafolyamatokat nagymértékben megnehezítené, hogyha a folyadékok egy bontási müvelet során kerülnének felszínre. A bemenő raktárakban parkolnak a bontásra szánt járművek, illetve a kimenő raktárban a kibontott alkatrészek és hulladékok frakciónként külön tárolókban kerülnek elhelyezésre. Ha a be- és kimenő raktár egy csarnokban van, azt fejraktárnak nevezzük. A bontóállomásokon kiszerelt egységek és alkatrészek az átmeneti tárolókban gyülnek, ha az megtelik, átszállításra kerülnek a kimenő raktárba.

A bemutatott objektumok közül a szárazra fektető állomás rendelkezik egyedi kötöttségekkel a célgépek és berendezések miatt, ezért ennek az állomásnak dedikált helyen kell lennie az üzemcsarnokon belül. A többi objektum elhelyezkedése kevésbé megkötött, így ennek függvényében az egyes objektumok egymáshoz viszonyított elhelyezkedése kiemelkedő szerepet tölthet be a 
bontóüzem logisztikai teljesítményének vizsgálata során. Egy új bontóüzem tervezésekor úgy célszerü meghatározni a tevékenységhez szükséges anyagáramlási relációkat, hogy az anyagmozgatási összmunka minimális legyen.

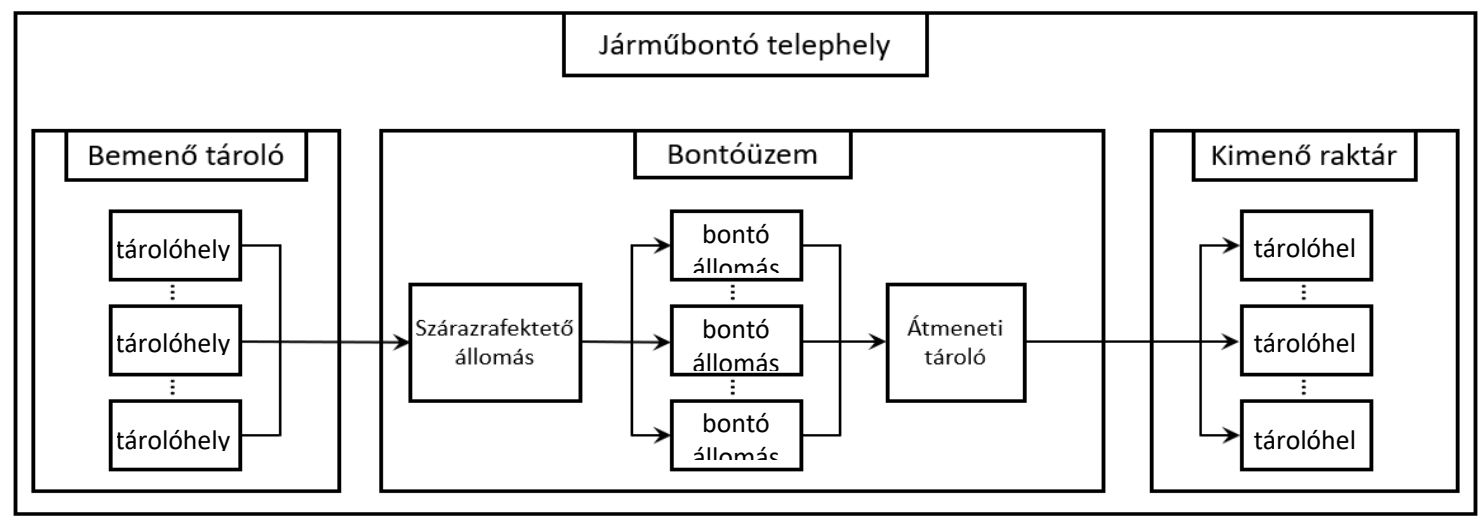

3. ábra Jármübontó belső anyagáramlásának ábrája [12]

Az elrendezés-tervezésnél az anyagmozgatás optimalizálásának célfüggvénye: [10]

$$
W=\sum_{j=1}^{m} \sum_{i=1}^{n} q_{i j} \cdot l_{i j} \rightarrow \min .
$$

ahol:

$\boldsymbol{q}_{\boldsymbol{i j}}-$ az $\boldsymbol{i}$-edik feladóhelyröl a $\boldsymbol{j}$-edik leadóhelyre áramló anyagmennyiség $[\boldsymbol{k g}]$,

$\boldsymbol{l}_{\boldsymbol{i} \boldsymbol{j}}-$ a bontóüzem $\boldsymbol{i}-\boldsymbol{j}$ relációjában a szállítási úthossz $[\boldsymbol{m}]$.

Egy már meglévő bontóüzem hatékonyságának növelése bonyolult és költséges. Hatékonyabb rendszer létrehozásához, azaz a jelenlegi rendszer fejlesztéséhez az anyagmozgatási munka minimalizálása a cél, de számolni kell bizonyos számú megkötésekkel. [11] Minden esetben felrajzolható a jelenlegi rendszer anyagáramlási gráfja, ami vizuális oldalról ad lehetőséget az anyagmozgatási rendszer vizsgálatára. Ez a gráf tartalmazza az egyes objektumok között áramló anyagmennyiségeket és azok irányait. Ezen gráf alapján felírható az aktuális rendszer anyagáramlási mátrixa $[Q]$. Ezen kívül szükséges feltárni a rendszer objektumaira vonatkozó távolság mátrixot is $[L]$, amelyben az összes lokáció egymáshoz viszonyított távolsága van megadva. Ezekből kiszámítható az anyagmozgatási munka a (3) képlet alapján, amely egy alkalmas mutatószám a rendszer minősítésére logisztikai szempontból. [10] Az anyagmozgatási munka (W) a [Q] és az [L] mátrixok azonos helyein lévő értékek szorzatösszege. Az így kapott teljesítménymutató képes megfelelően minősíteni az adott rendszert. [13]

A rendszerekben történő változtatás (például az egyirányú anyagáramlás megvalósítása vagy ütközések kiküszöbölése) a (3) képlet szerint eltérő eredményeket ad. Az anyagmozgatási munka ebben az esetben csökkenhet, vagy növekedhet. Ezáltal ennek a számítási eljárásnak a használata képes kielégítően támogatni a fejlesztési döntéseket. [14]

Fejlesztési lépések:

1. lépés: feltárni a rendszerhatárokat, az esetleges korlátozásokat és megkötéseket,

2. lépés: szükség esetén változtatni a nem kötött objektumok elrendezésén,

3. lépés: több alternatív rendszerterv elkészítése, 
4. lépés: anyagmozgatási munka kiszámítása a rendszerterv-változatokra,

5. lépés: a rendszerterv-változat megvalósításánál felmerülő költségek meghatározása, vagy becslése,

6. lépés: összevetni az eredményeket és a megvalósíthatóságot.

Az 5. lépés azt jelenti, hogy a rendszerterv-változatok súlyozásánál a költségek minimalizálását fogjuk megadni, mint elérendő célt.

Ehhez szükséges bevezetni a $\boldsymbol{K}_{\boldsymbol{a} m}^{\boldsymbol{k}}$ költség-paramétert, amely a $k$-adik számú jármü bontásánál jelentkező anyagmozgatási munka és a fajlagos anyagmozgatási költség szorzataként értelmezhető:

$$
K_{a m}^{k}=\sum_{j=1}^{m} \sum_{i=1}^{n}\left(q_{i j}^{k} \cdot l_{i j}\right) \cdot k_{a m}
$$

ahol:

$\boldsymbol{q}_{i j}^{\boldsymbol{k}}$ - az $\boldsymbol{i}$-edik feladóhelyről a $\boldsymbol{j}$-edik leadóhelyre áramló anyagmennyiség a $\boldsymbol{k}$-adik jármü szétbontása esetén $[\mathbf{k g}]$,

$\boldsymbol{l}_{\boldsymbol{i j}}-$ a bontóüzem $\boldsymbol{i}-\boldsymbol{j}$ relációjában a szállítási úthossz $[\boldsymbol{m}]$,

$\boldsymbol{k}_{\boldsymbol{a m}}-$ a telephelyen belüli anyagmozgatás fajlagos költsége $[\boldsymbol{F t} / \mathbf{k g m}]$.

Továbbá szükséges megemlíteni egy költséget, amely befolyásolja a döntéstámogatást, ez a $\boldsymbol{K}_{\boldsymbol{f}}$ fejlesztési költség, amely egy egyszeri jelleggel (időben pontszerüen) megjelenő fejlesztési, vagy beruházási költség.

Ezáltal a hatékony rendszerterv kiválasztását támogató kétparaméteres célfüggvény:

$$
\sum_{k=1}^{o}\left[\sum_{j=1}^{m} \sum_{i=1}^{n}\left(q_{i j}^{k} \cdot l_{i j}\right)\right]_{k} \cdot k_{a m}+K_{f} \rightarrow \min .
$$

ahol:

$\boldsymbol{o}$ - a vizsgált időtartományban a szétbontásra kerülő jármüvek száma,

$\boldsymbol{q}_{\boldsymbol{i j}}^{\boldsymbol{k}}$ - az $\boldsymbol{i}$-edik feladóhelyről a $\boldsymbol{j}$-edik leadóhelyre áramló anyagmennyiség a $\boldsymbol{k}$-adik jármü szétbontása esetén $[\mathrm{kg}]$,

$\boldsymbol{l}_{\boldsymbol{i} \boldsymbol{j}}-\mathrm{a}$ bontöüzem $\boldsymbol{i}-\boldsymbol{j}$ relációjában a szállítási úthossz $[\boldsymbol{m}]$,

$\boldsymbol{k}_{\boldsymbol{a m}}-$ a telephelyen belüli anyagmozgatás fajlagos költsége $[\boldsymbol{F t} / \mathbf{k g m}]$,

$\boldsymbol{K}_{\boldsymbol{f}}-$ a teljes fejlesztés/beruházás költsége $[\boldsymbol{F t}]$.

Azt a rendszerterv-változatot érdemes kiválasztani a fejlesztéshez, amelyik a legalacsonyabb anyagmozgatási munkát biztosítja a legkisebb fejlesztési költségek mellett. A (5) összefüggés alapján látható, hogy nem az a legköltséghatékonyabb rendszerterv, ahol a legalacsonyabb az anyagmozgatási munka. A rendszerterveket érdemes szimulációs eljárásokkal ${ }^{[15]}$ is tovább vizsgálni a fejlesztés megvalósítása előtt.

\section{Köszönetnyilvánítás}

A cikkben ismertetett kutató munka az EFOP-3.6.1-16-2016-00011 jelü „Fiatalodó és Megújuló Egyetem - Innovatív Tudásváros - a Miskolci Egyetem intelligens szakosodást szolgáló intézményi fejlesztése" projekt részeként - a Széchenyi 2020 keretében - az Európai Unió támogatásával, az Európai Szociális Alap társfinanszírozásával valósul meg. 


\section{5. Összefoglalás}

A körforgásos gazdasági modell sokrétüen beépülhet az ipar számos területére. Egy jármübontó logisztikai vizsgálata és fejlesztése jól példázza, hogy a külső- és belső logisztikai folyamatokat miként lehet hatékonyabbá, gazdaságosabban végezhetőbbé tenni. A logisztikai folyamatok optimalizálása mindig kihívást fog jelenteni egy olyan iparban, ahol nem a megszokott összeszerelés, vagy gyártás zajlik. Ezáltal belátható, hogy egy folyamat akkor maradhat életképes, ha bizonyos esetekben képes bevételt termelni. Az újrahasznosítási tevékenységek nem szokványosak egyes szolgáltatási és ipari területeken, mivel nem lehet ezeket profitorientált módon végezni. Viszont újabb termékdíjjal terhelhető kategóriák bevezetésével és a szabályozás komplex szerkezetekre történő kiterjesztésével előirányozható az újrahasznosítási folyamatok széleskörü elterjedése több ipari területhez illeszkedve.

\section{Irodalom}

[1] Geissdoerfer, M., Savaget, P., Bocken, N., Hultink E. J.: The Circular Economy - A new sustainability paradigm? Journal of Cleaner Production 2017, 143:757-768. https://doi.org/10.1016/j.jclepro.2016.12.048

[2] Circular Economy in the Tourism Sector https://www.hospitalitynet.org/opinion/4095249.html

[3] Fogarassy, Cs., Horváth, B.: A körkörös gazdaság értelmezése. Lépések a fenntarthatóság felé 2018, 23(2):4-5.

[4] Fogarassy, Cs.: Lineáris vs. körkörös ellátási láncok, Lépések a fenntarthatóság felé 2018, 23(2):3.

[5] Horváth, B.: Körkörös gazdasági modellek hatékonyságának mérése, PhD értekezés, SZIE Gazdálkodás és Szervezéstudományok Doktori Iskola (2019)

[6] KörkörösGazdaság http://korkorosgazdasag.hu/category/elgondolkodtato/page/12/

[7] 369/2014. (XII. 30.) Korm. rendelet a hulladékká vált gépjármüvekről

[8] 2011. évi LXXXV. törvény a környezetvédelmi termékdíjról

[9] Központi Statisztikai Hivatal. Tájékoztatási adatbázis - Jármüállomány (https://www.ksh.hu/docs/hun/xstadat/xstadat_eves/i_ode006a.html?down=779)

[10] Cselényi, J., Illés, B.: Anyagáramlási rendszerek tervezése és irányítása I., Miskolci Egyetemi Kiadó, ISBN 963661 6728, Miskolc-Egyetemváros (2006)

[11] Cselényi, J., Illés, B.: Logisztikai rendszerek I., Miskolci Egyetemi Kiadó, MiskolcEgyetemváros (2004)

[12] Prezenszki, J.: Logisztika I. (Bevezető fejezetek), BME Mérnöktovábbképző Intézet, ISBN 963 431 7960, Budapest (2004)

[13] Juhász, J., Bányai, T.: Intelligens szállítási rendszerek logisztikai vonatkozásai, In: Vadászné, Bognár, G.; Piller, I. (szerk.) Doktoranduszok Fóruma 2017.: Gépészmérnöki és Informatikai Kar szekciókiadványa Miskolc, Magyarország: Miskolci Egyetem Tudományos és Nemzetközi Rektorhelyettesi Titkárság, pp. 38-43., 6 p. (2018)

[14] Prezenszki, J.: Logisztika II. (Módszerek, eljárások), Logisztikai Fejlesztési Központ, ISBN 963036 7408, Budapest (2004)

[15] Juhász, J., Bányai, T.: Optimization in city logistics, In: Schenk, M. (szerk.) 12th International Doctoral Students Workshop on Logistics, Magdeburg, Németország: Otto von GuerickeUniversität Magdeburg, (2019) pp. 113-118., 6 p. (2019) 